\title{
PALESTINIAN NGOs: EXTERNAL GOVERNANCE, STAKEHOLDERS, AND ACCOUNTABILITY
}

\author{
Raed Awashreh \\ Independent researcher, occupied Palestinian territory \\ Email: awashreh_raed@yahoo.com
}

DOI: https://doi.org/10.18196/jgpp.5296

Article Info

Article history:

Received 22 Apr 2018

Revised 21 May 2018

Accepted 30 May 2018

\section{Keywords:}

Governance, Stakeholders, NGOs, Palestinian, and UpwardDownward Accountability.

\begin{abstract}
This article addresses nongovernment organizations (NGOs) accountability, relationship with stakeholders, and what kind of mechanisms - tools or processes have NGOs put in place to ensure all types of accountabilities. The assumption in this study is that Palestinian NGOs, individually and collectively, are more accountable to their donors and to the Palestinian Authority to a lesser extent as NGOs need these two which are the only stakeholders with a real power to exercise on the NGOs and enforce their accountability requirements. The research argues that stakeholders' power is therefore determining NGO accountability. The findings highlighted the failure of NGOs in meeting the most pressing needs of the public and the poor in particular. The upward-accountability also signals of the sector's inability to consolidate its legitimacy or define an agenda or develop down-ward accountability. On top of that, political parties' involvement in the non-profit organizations is another factor that has compounded the sector's lack of public accountability, negative competitiveness, fragmentation, selfserving leadership, and exploitation as a substitute of political arena. In NGOs' opinion, the relationships to various stakeholders range from satisfactory to good especially where the PA, foreign donors, and political factions are concerned. The PA's hostility towards NGOs stems from suspicion of their political or donor affiliations and NGOs critique of PA policies and performance. However, NGOs accountability flows towards two powerful external stakeholders, the donors and the PA. Consequently, the NGOs are more concerned with upward accountability than with down-ward ones such as to the general public and the non-profit sector as a whole. Finally, NGOs accountability dilemma is both a cause and a result of low level of public participation in NGOs affairs due to public's lack of trust and the general feeling that NGOs are distant, self-absorbed, and wasting foreign funds on activities lacking sufficient relevance to actual needs.

This conclusion based on huge investigation, a combination of qualitative and quantitative methodologies, survey, interview, focus groups in the West Bank, gathering huge data to build a theory from the field

ABSTRAK
\end{abstract}

Artikel ini membahas akuntabilitas organisasi non-pemerintah (LSM), hubungan dengan para pemangku 
kepentingan, dan mekanisme seperti apa - alat atau proses yang dimiliki LSM untuk memastikan semua jenis akuntabilitas. Asumsi dalam penelitian ini adalah bahwa LSM Palestina, secara individu dan kolektif, lebih bertanggung jawab kepada donor mereka dan kepada Otoritas Palestina pada tingkat yang lebih rendah karena LSM membutuhkan kedua yang merupakan satu-satunya pemangku kepentingan dengan kekuatan nyata untuk melaksanakan pada LSM dan menegakkan persyaratan akuntabilitas mereka. Penelitian ini berpendapat bahwa kekuatan pemangku kepentingan karenanya menentukan akuntabilitas LSM. Temuan ini menyoroti kegagalan LSM dalam memenuhi kebutuhan paling mendesak dari masyarakat dan orang miskin pada khususnya. Akuntabilitas ke atas juga menandakan ketidakmampuan sektor untuk mengkonsolidasikan legitimasinya atau mendefinisikan agenda atau mengembangkan akuntabilitas di tingkat bawah. Di atas itu, keterlibatan partai politik dalam organisasi nirlaba adalah faktor lain yang telah memperumit kurangnya akuntabilitas publik, daya saing negatif, fragmentasi, kepemimpinan yang melayani diri sendiri, dan eksploitasi sebagai pengganti arena politik. Menurut pendapat LSM, hubungan dengan berbagai pemangku kepentingan berkisar dari memuaskan hingga baik, terutama ketika PA, donor asing, dan fraksi politik prihatin. Permusuhan PA terhadap LSM berasal dari kecurigaan afiliasi politik atau donor mereka dan kritik LSM terhadap kebijakan dan kinerja PA. Namun, akuntabilitas LSM mengalir ke arah dua pemangku kepentingan eksternal yang kuat, para donor dan PA. Konsekuensinya, LSM lebih peduli dengan akuntabilitas ke atas daripada dengan yang lebih rendah seperti ke masyarakat umum dan sektor nirlaba secara keseluruhan. Akhirnya, dilema akuntabilitas LSM merupakan penyebab dan akibat rendahnya tingkat partisipasi publik dalam urusan LSM karena kurangnya kepercayaan masyarakat dan perasaan umum bahwa LSM berada jauh, menyerap diri, dan membuang dana asing pada kegiatan yang tidak memiliki relevansi yang cukup untuk kebutuhan sebenarnya. Kesimpulan ini didasarkan pada penyelidikan besar, kombinasi metodologi kualitatif dan kuantitatif, survei, wawancara, kelompok fokus di Tepi Barat, mengumpulkan data besar untuk membangun teori dari lapangan

\section{INTRODUCTION}

Governance refers to "all the ways in which people collectively make choices" (Florini cited in McIntyre-Mills, 2008, p. 19). For organizations, stakeholders come together to cooperate tactically on the short term to accomplish their common interests and goals. 
Recognizing the transitory nature of common goals and power of selfinterest, Lord Palmerston once said "a country does not have permanent friends, only permanent interests" (Weijiang, 2010, para. 18). This means that ethical values and social interests should be the most important aspects to nongovernment organizations (NGOs) governance when taking decisions affecting present and future generations (McIntyre-Mills, 2008, p. XXXVIII).

Previous researchers show that foreign aid has positive and negative outcomes at almost all levels: economic, political and social as well as at the NGOs sector. So instead of rejecting foreign aid, Palestinian organizations want to reform aid management, because this is the only proposition that allows funding flow to continue. Even with that call, NGOs have yet to develop a unified vision of community work and an agenda for the non-profit sector in line with people's expectations, needs and goals.

This article addresses NGOs accountability and relationship with stakeholders. Taking into consideration the Palestinian people as their life is affected by decisions taken by local or international actors, the research tries to answer three important questions: Firstly, what is the nature of current NGOs relationship with stakeholders, and to what extent politics and money play a role in relationship dynamic? Secondly, to what extent the Palestinian NGOs are accountable to their stakeholders namely: local communities/ or public, Palestinian Authority (PA), donors, and the Palestinian national goals? Thirdly, what kind of mechanisms, tools or processes have NGOs put in place to ensure all types of accountabilities? The answers will shed more light on NGOs accountability (internal and external) towards their stakeholders, especially towards local communities and the public at large. To serve this purpose, the article investigates different topics to reflect on NGOs external accountability because NGOs participate in 'state' building and are responsible for building trust with their constituencies and stakeholders. The assumption in this study is that Palestinian NGOs, individually and collectively, are more accountable to their donors and to the Palestinian Authority to a lesser extent as NGOs need these two which are the only stakeholders with a real 
168 power to exercise on the NGOs and enforce their accountability requirements. The research argues that stakeholders' power is therefore determining $\mathrm{NGO}$ accountability direction. For various reasons, NGO-donor relationship is stronger than NGO- PA relationship which obligates NGOs to remain accountable to donors to ensure sustainability of funding. On the other hand, NGOs are forced to fulfilling PA legal requirements, even when illegal, because the PA can exercise coercive power on the NGO sector.

To investigate on this issue, a combination of qualitative and quantitative methodology has adopted, using primary and secondary data over NGOs in the West Bank to build a theory from the field. Five main data collection instruments uses here: (1) a structured sixpage survey was distributed to a pre-selected sample of forty organizations. 40 adult respondents selected from NGOs across the West Bank. A perception survey on the opinions and positions of 100 NGO staff members carried out using a one-page structured survey. (2) Face to face interviews with 53 interviewees representing a wide range of NGOs, relevant PA institutions, local organizations, donors, and civil society activists and experts. Each semi-structure interview took $1 / 2-2$ hours to complete, especially if the interviewee has many professional capacities or formal roles in the community (i.e. university professors, mayors, and NGO board members, etc. (3) Three focus group discussions for NGOs members and activists in the West Bank. The researcher called selected organizations to explain the purpose and nature of the research and the issues to be addressed in the focus groups, and agree on suitable day, time, place, and other logistical issues ${ }^{1}$. The three- hour focus groups were held: one in district of Tulkarem, El-Kafreyat rural areas, and two more held in the town of Beit Rima and Al-Amari Refugee camp in Ramallah district. The second focus group in Ramallah had participants selected from refugee camps in Ramallah, Jerusalem and Jericho

\footnotetext{
${ }^{1}$ Sometimes, I spent the entire day was spent in one community doing interviewing and talking to the residents as well as to gain people's trust prior to data collection. Some locations preferred meeting in the afternoon or in weekends and demanded that I make arrangement for their transport.
} 
districts. (4) Three case studies were undertaken on a number of urban and rural-based CBOs and NGOs in the target districts. The case studies were developed through interviews and additional focus groups discussions. The target localities were chosen because of the researcher's familiarity with their social contexts and for their physical proximity conducive to frequent field visits for data collection. (5) In addition, six exploratory meetings with key informants and experts were held to solicit their views and ideas on the issues under investigation. They are located in the city of Ramallah and approached on their expertise and ability of cooperation.

The research is divided into four sections; the first section discusses stakeholders' expectations of NGOs while the second section addresses NGOs relationship with their stakeholders such as the PA, political factions and local governments. The third section discusses NGOs accountability to the NGOs sector, future generations and the Palestinian national goals. The last section covers NGOs legitimacy and identity and describes the prevailing mentality of accountability within the non-profit sector in the oPt.

\section{Stakeholders Expectations of NGOs}

'Stakeholders' is originally a private sector concept delineating those with ownership-based power, i.e. owners of the majority of stocks in a firm (Mitchell, Agle, \& Wood, 1997). NGOs have several stakeholders, most important are four: donors, the state, NGO governing bodies, and the general public.

Previous research established that the main public needs are: poverty reduction, employment generation and improvement of education and health services. NGOs give primacy to these practical needs over the collective national rights. The politically-motivated foreign funding helps mitigate the negative impact of occupation and sustain the PA not as a sovereign state but as Palestinian self-rule machinery co-existing with the occupation. Instead of being on equal footing with their partner NGOs, donors are the most powerful party due to their financial strengths (DW., interview, 22 April). Donors also encourage NGOs to embrace a pro- democracy and participatory 
17 public policy agendas all seen as Western and donor-driven political agendas (EH., interview, 15 December).

This research does not focus on 'basic needs for survival' but rather adopts the notion of community needs in a general sense and what people believe is necessary to enhance the quality of their lives. As a semi-state, the PA lacks control over Palestinian resources which entails that the private and non-profit sector must shoulder some of the state's responsibility by being responsive to the public. The public expects NGOs to address their service related worries, quality and quantity-wise, and contribute to infrastructure development. NGOs adopt a narrow perspective to service provision and a narrower one regarding NGOs role in political empowerment of the public or enhancing Palestinian national identity.

None of the focus group participants or interviewees listed democracy, human rights, or gender as part of their immediate public needs or concerns. Few members of Board of Director $(\mathrm{BoD})$ stated that people are more concerned with a 'free ride' rather than the general public interests because NGOs are seen as sources of free assistance and humanitarian relief (BA., KH., and JI., interview, 10 May). One BoD member pointed out that: "It is the rich rather than the poor who always seek NGOs assistance. About $60-65 \%$ of food rations recipients are rich. People not needing food aid complain to us that they are not treated equally with those benefiting from food baskets" (JI., interview, 10 May).

This is one factor behind the 'charity mentality' or 'begging culture' in the oPt which is blamed for the decline of voluntary work and community spirit among the public and NGOs' activities and strategic thinking.

Previous researches states that NGOs emphasize relief, health and education while very few work with communities negatively impacted by the Separation Wall (HA., interview, 10 February; HE., interview, 2 February; M.B., interview, 30 March). Similarly, Table (6.1) below shows that $18 \%$ of surveyed staff and $37 \%$ of top management believe that NGOs benefits the poor compared to $15 \%$ and $52 \%$ who believed that this work is beneficial to the general public. 
Table 1: Top Management \& Staff Perceptions of Beneficiaries of NGOs work

\begin{tabular}{|l|l|l|l|l|l|l|}
\hline \multirow{2}{*}{ Statement } & \multicolumn{2}{|l|}{$\begin{array}{l}\text { Weak } \\
(\mathbf{1 - 2})\end{array}$} & \multicolumn{2}{l|}{$\begin{array}{l}\text { Satisfactory } \\
\mathbf{( 3 )}\end{array}$} & \multicolumn{2}{l|}{$\begin{array}{l}\text { Good } \\
\mathbf{( 4 - 5 )}\end{array}$} \\
\cline { 2 - 7 } & Mgt & Staff & Mgt & Staff & Mgt & Staff \\
\hline $\begin{array}{l}\text { NGOs work is } \\
\text { beneficial to the } \\
\text { public }\end{array}$ & $37.5 \%$ & $85 \%$ & $25 \%$ & $15 \%$ & $27.5 \%$ & $0 \%$ \\
\hline $\begin{array}{l}\text { The Poor benefit from } \\
\text { NGOs work }\end{array}$ & $62.5 \%$ & $82 \%$ & $17.5 \%$ & $18 \%$ & $20 \%$ & $0 \%$ \\
\hline $\begin{array}{l}\text { NGOs enhance the } \\
\text { quality of public life }\end{array}$ & $52.5 \%$ & $84 \%$ & $25 \%$ & $15 \%$ & $22.5 \%$ & $1 \%$ \\
\hline $\begin{array}{l}\text { NGOs contribute to } \\
\text { infrastructure building }\end{array}$ & $74 \%$ & 80.6 & $23.1 \%$ & 19.4 & $2.6 \%$ & $0 \%$ \\
\hline $\begin{array}{l}\text { NGOs contribute to } \\
\text { human rights } \\
\text { promotion }\end{array}$ & $55 \%$ & $78 \%$ & $30 \%$ & $20 \%$ & $15 \%$ & $2 \%$ \\
\hline $\begin{array}{l}\text { NGOs effort to } \\
\text { promote democracy }\end{array}$ & $47.5 \%$ & $59 \%$ & $35 \%$ & $39 \%$ & $17.5 \%$ & $2 \%$ \\
\hline
\end{tabular}

Sample size: 40 Top Mgt. and 100 staff. On a scale from 1- 5: very weak (1), weak (2), satisfactory (3), good (4), and very good (5). The scale is regrouped to indicating weak (1-2), satisfactory (3) and good (4-5).

The above figures also indicate that NGOs are more active in human rights and democracy than in other fields. About $31 \%$ of staff and $52 \%$ of management stated that NGOs contribute positively to the promotion of human rights and democracy. NGOs seem to work within scope of international organizations and donors and bring to their areas what the donors allow them to offer.

\section{NGOs Relationship with Stakeholders}

Politics and money are the most important factors defining the NGOs relationship with their stakeholders. Soliciting external funding is not a new industry among Palestinian NGOs (TB., interviews, 20 February; M.B., interview, 30 March). For decades, PLO paid Palestinian universities student tuitions and staff salaries and allocated budgets to political factions and sometimes NGOs working inside the Occupied Territories. The NGOs had followed PLO political agendas as long as PLO remained influential and commanded financial resources (Nakhleh, 1989). 
10 Today, the relationship between NGOs and stakeholders follow a similar pattern. The organizational and staff surveys in table 6.2 show that the highest mean, i.e. better relationship, exists between the NGOs and political parties. On scale of $1-5$, both managers and staff have the highest response mean of 3.38 and 2.9 respectively. The second highest mean (i.e. best performance) is found in the current monitoring by the Ministry of Interior Affairs (MoI) and cooperation with local government where scores ranged between 2.83 and 2.96. The lowest mean (i.e. worst performance) is indicated in monitoring of NGOs activities by line ministries, which is the role usurped by the MoI.

Table 2: Perceptions of Current NGO relations to few External Stakeholders

\begin{tabular}{|l|l|l|l|l|l|l|}
\hline $\begin{array}{l}\text { Relation } \\
\text { with } \\
\text { Stakeholders }\end{array}$ & \multicolumn{2}{|l|}{ Management } & \multicolumn{2}{l|}{ Staff } & \multicolumn{2}{l|}{ Mean } \\
\cline { 2 - 7 } & Weak & $\begin{array}{l}\text { Satisfactory- } \\
\text { very good }\end{array}$ & Weak & $\begin{array}{l}\text { Satisfactory } \\
- \text { very good }\end{array}$ & Mgt & Staff \\
\hline $\begin{array}{l}\text { Monitoring by } \\
\text { Ministry of Interior }\end{array}$ & $37.5 \%$ & $62.5 \%$ & $27.5 \%$ & $72.5 \%$ & 2.90 & 2.83 \\
\hline $\begin{array}{l}\text { Monitoring by line } \\
\text { ministries }\end{array}$ & $53.8 \%$ & $46.2 \%$ & $63.0 \%$ & $37.0 \%$ & 2.36 & 1.93 \\
\hline $\begin{array}{l}\text { Cooperation with } \\
\text { NGOs (sector) }\end{array}$ & $47.5 \%$ & $52.5 \%$ & $45.0 \%$ & $55.0 \%$ & 2.42 & 2.28 \\
\hline $\begin{array}{l}\text { Relationship with } \\
\text { political parties }\end{array}$ & $48.7 \%$ & $61.3 \%$ & $50.0 \%$ & $50.0 \%$ & 3.38 & 2.97 \\
\hline $\begin{array}{l}\text { Cooperation with } \\
\text { political parties }\end{array}$ & $57.9 \%$ & $52.1 \%$ & $62.6 \%$ & $37.4 \%$ & 2.32 & 2.53 \\
\hline $\begin{array}{l}\text { Cooperation with } \\
\text { local government }\end{array}$ & $40.0 \%$ & $60.0 \%$ & $46.0 \%$ & $54.0 \%$ & 2.83 & 2.96 \\
\hline
\end{tabular}

Sample size included 40 Top Mgt. officials, and 100 staff members. On a scale of 1-5: 1 represents very weak, 2 weak, 3 satisfactory, 4 good, and 5 very good. The ranking is re-grouped to weak (1-2), satisfactory - very good (3-5).

\subsection{Relationship with the Palestinian Authority}

As said before, the MoI is the main PA agency with the mandate to regulate NGOs affairs, although technical supervision and licensing are assigned to other line ministries (social affairs, sport, women, education, youth, and agriculture). In fact, line ministries undertake the least of oversight as indicated by $54 \%$ of surveyed $\mathrm{BoD}$ members and $63 \%$ of NGOs staff who described this role as weak. In the table 
below, the lowest score comes from service delivery organizations which ironically should be more subject to oversight by line ministries than advocacy NGOs or organizations with combined mandates.

Table 3: Respondents' Satisfaction of PA Monitoring, by Type of Organization

\begin{tabular}{|l|l|l|l|l|l|l|l|l|}
\hline \multirow{2}{*}{\begin{tabular}{l} 
Type of $\begin{array}{l}\text { Organizat } \\
\text { ion }\end{array}$ \\
\cline { 2 - 9 }
\end{tabular}} & $\begin{array}{l}\text { Monitoring by Ministry of Interior } \\
(1-2)\end{array}$ & $\begin{array}{l}\text { Satisfacto } \\
\text { ry (3) }\end{array}$ & $\begin{array}{l}\text { Good } \\
(4-5)\end{array}$ & Total & $\begin{array}{l}\text { Weak } \\
(1-2)\end{array}$ & $\begin{array}{l}\text { Satisfac } \\
\text { tory (3) }\end{array}$ & $\begin{array}{l}\text { Good } \\
(4-5)\end{array}$ & Total \\
\hline NGO & 6 & 5 & 6 & 17 & 9 & 7 & 0 & 16 \\
\hline CBO & 9 & 6 & 8 & 23 & 12 & 6 & 5 & 23 \\
\hline Total & $\mathbf{1 5}$ & $\mathbf{1 1}$ & $\mathbf{1 4}$ & $\mathbf{4 0}$ & $\mathbf{2 1}$ & $\mathbf{1 3}$ & $\mathbf{5}$ & $\mathbf{3 9}$ \\
\hline Advocacy & 4 & 1 & 3 & 8 & 6 & 2 & 0 & 8 \\
\hline Services & 9 & 8 & 7 & 24 & 11 & 8 & 5 & 24 \\
\hline Both & 2 & 2 & 4 & 8 & 4 & 3 & 0 & 7 \\
\hline Total & 15 & 11 & 14 & $\mathbf{4 0}$ & 21 & 13 & 5 & $\mathbf{3 9}$ \\
\hline
\end{tabular}

Sample size included 40 NGO Top Mgt. officials, 1 did not answer.

Table 6.4 also shows that NGOs demand a larger role for line ministries. All NGOs managers responded with a preference for oversight by line ministries; more than $81 \%$ of surveyed staff who believed that the MoI should undertake a lesser supervisory role because two-thirds of staff members (63\%) believe that the MOI's oversight is rather weak.

Table 4: NGOs Satisfaction of Monitoring by MoI and Line Ministers

\begin{tabular}{|l|l|l|l|l|}
\hline Statement & Group & $\begin{array}{l}\text { Weak } \\
(1-2)\end{array}$ & $\begin{array}{l}\text { Satisfactory } \\
(3)\end{array}$ & $\begin{array}{l}\text { Good } \\
(4-5)\end{array}$ \\
\hline $\begin{array}{l}\text { NGOs monitoring/oversight } \\
\text { is done by line ministries }\end{array}$ & Mgt. & $53.8 \%$ & $33.3 \%$ & $12.9 \%$ \\
\cline { 2 - 5 } & Staff & $63 \%$ & $37 \%$ & - \\
\hline $\begin{array}{l}\text { NGOs monitoring/oversight } \\
\text { is done by Ministry of } \\
\text { Interior }\end{array}$ & Mgt. & $27.5 \%$ & $35 \%$ & 2.9 \\
\cline { 2 - 5 } & Staff & $63 \%$ & $37 \%$ & - \\
\hline $\begin{array}{l}\text { NGOs monitoring/oversight } \\
\text { should be done by line } \\
\text { Ministries }\end{array}$ & Mgt & $0 \%$ & $0 \%$ & $100 \%$ \\
\cline { 2 - 5 } $\begin{array}{l}\text { NGO monitoring/oversight } \\
\text { should be done by the } \\
\text { Ministry of Interior }\end{array}$ & Staff & $2 \%$ & $17 \%$ & $81 \%$ \\
\cline { 2 - 5 } & Staff & $17.5 \%$ & $10 \%$ & $72.5 \%$ \\
\hline
\end{tabular}

Sample size included 40 NGO Top Mgt. officials, and 100 staff members.

It is not be surprising that politically affiliated NGOs generally prefer not to be directly monitored by the $\mathrm{MoI}$ and its 
171 security forces except for Fateh- affiliated NGOs. The latter groups enjoy better relations with the MoI and other PA institutions and have wider margin for free speech and criticism of PA performance. Some MoI employees serve as $\mathrm{BoD}$ members of many NGOs (Kafreyat focus group, 19 March). The Beit Rima focus group also accused the PA of favouritism, politicization and discrimination in the registration. Furthermore, PA is alleged allocate disproportional funding to some NGOs from its budget and deliberately neglects to announce available fund to the NGO sector. The focus group reported on a case where the Prime Minister's Office declined an NGO request for PA contribution to the renovation of a historical site (Beit Rima focus group, 4 April). Similarly, refugee communities accuse the PA of neglecting refugee camps and the right to return (ElAmari focus group, 31 May). In another example, in 2009, during the Israeli war on Gaza, the PA forced NGOs to stop their fundraising campaigns because the money shall benefiting Gaza Strip under Hamas control (Beit Rima focus group, 4 April). Even cooperatives are now subjected to the same security clearance before registration after June 2007 because the PA does not want Hamas to function through cooperatives or NGOs in the West Bank. Therefore, some organizations keep their interaction with the PA to the minimum legal requirements such as registrations and financial reporting.

\subsection{Relationship with Political Factions}

The findings of both surveys show that NGOs relationships with political parties are not bad in general but NGOs sector calls for stronger relationships and coordination with political factions. This tendency is apparent among NGOs staff (90\%) more than managers $(55 \%)$ as shown in the table below.

Table 5: Perceptions of Top Management and Staff of NGO Relations to Political Factions

\begin{tabular}{|c|c|c|c|c|c|}
\hline Statement & Group & Weak & Satisfactory & Good & Mean \\
\hline \multirow{2}{*}{$\begin{array}{l}\text { NGOs current relationship } \\
\text { with political parties is }\end{array}$} & Mgt & $48.7 \%$ & $28.2 \%$ & $23 \%$ & 2.54 \\
\hline & Staff & $50.0 \%$ & $24 \%$ & $26 \%$ & 2.90 \\
\hline \multirow{2}{*}{$\begin{array}{l}\text { NGOs relationship with } \\
\text { political parties should be }\end{array}$} & Mgt & $33.3 \%$ & $12.8 \%$ & $53.8 \%$ & 3.38 \\
\hline & Staff & $19.2 \%$ & $7.1 \%$ & $73.8 \%$ & 3.91 \\
\hline \multirow{2}{*}{$\begin{array}{l}\text { NGOs current cooperation } \\
\text { with political parties is }\end{array}$} & Mgt & $57.9 \%$ & $23.7 \%$ & $18.4 \%$ & 2.32 \\
\hline & Staff & $62.6 \%$ & $11.1 \%$ & $26.2 \%$ & 2.53 \\
\hline \multirow{2}{*}{$\begin{array}{l}\text { NGOs cooperation with } \\
\text { political parties should be }\end{array}$} & Mgt & $26.3 \%$ & $18.4 \%$ & $55.2 \%$ & 3.55 \\
\hline & & 8 & 2 & 8 & 4.20 \\
\hline
\end{tabular}


Moreover, the survey shows that men only and mixed-membership NGOs, along with organizations lacking strategic plans, want their relationships to be improved with political parties, while women's organizations were more vocal against that. Small organizations operating with less than USD 100,000 scored the highest in terms of existing cooperation although they demand more cooperation. Moreover, it is noticeable that district level NGOs call for better relationship compared to NGOs working at the West Bank level.

The data presented in table 6.6 shows some difference in NGOs outlook to political factions between various generations of NGOs. The surveyed NGOs and CBOs show fewer differences except that organizations working at the West Bank level are much more successful in such cooperation than their district or local counterparts. The table below also reveals that more than half of service delivery and advocacy organizations are not satisfied of their relationship with political parties. Interestingly, none of the preMadrid generation indicated good relations with political factions, while almost one third of the post-Oslo generations said they do.

Table 6: Relationships to Political Parties by Type of Organization

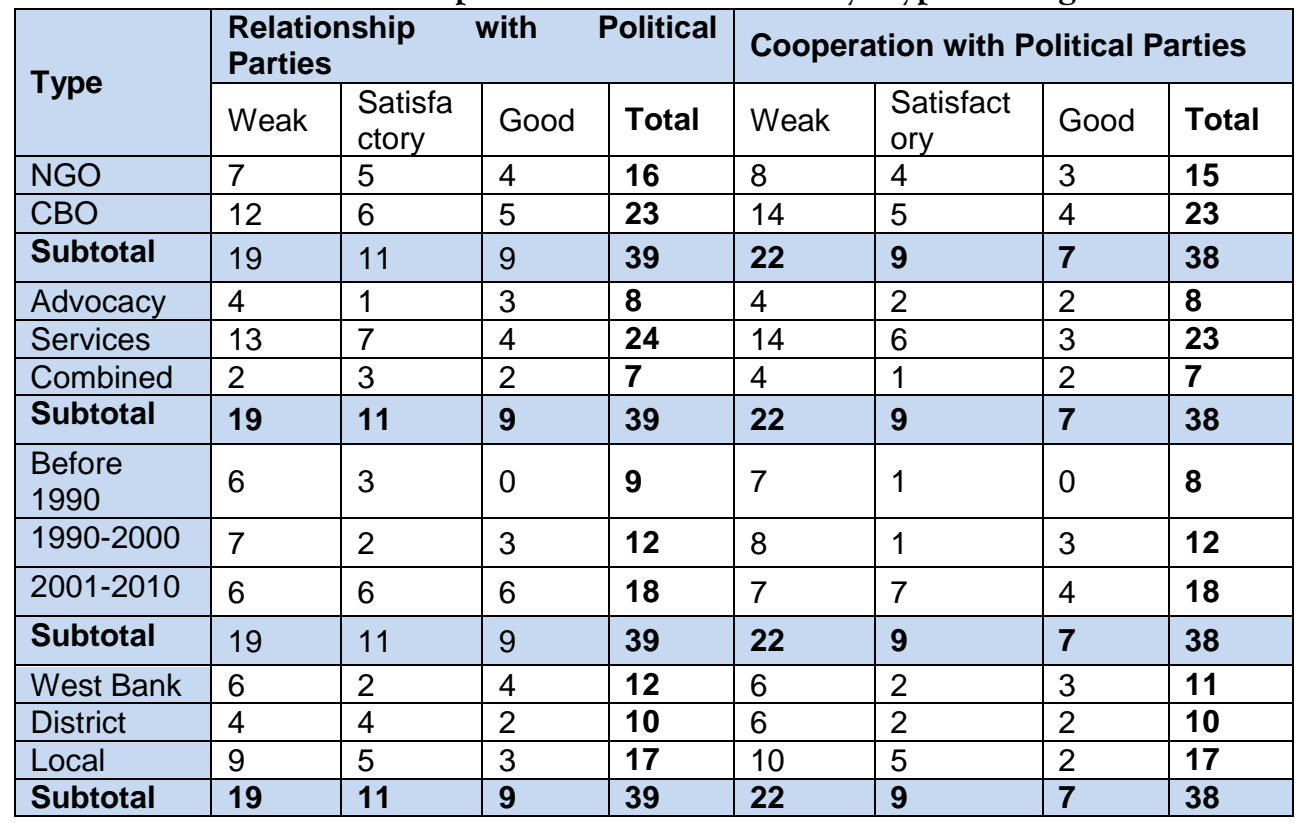


106 Sample size included 40 NGO Top Mgt., however, 1 did not answer relationship with political parties and 2 did not answer cooperation with political parties.

However, NGOs-political factions relationships are complex in the oPt which sometimes leads to negative consequences on the nonprofit sector. The findings indicate that politically-affiliated NGOs are used for personal interests as well as for generating support during elections (SA., interview, 1 February) and for providing their members with free services (Kafreyat focus group, 19 March ) or as a substitute for national struggle (ER., interview, 15 December).

Despite the fairly positive outlook, the interviews alluded to hidden conflicts between the BoDs and employees in politically affiliated NGOs. Disagreements revolved around whether the NGOs should adhere to professional criteria in the selection of employees and beneficiaries or work along the political party lines. For example, PARC $^{2}$ resisted pressure from the People's Party to hire its members as staff and the only beneficiaries of its programs (A.J., interview, 27 March). The conflict sometime reflects the mutual distrust and personal rivalries between senior members of political parties serving as members of NGOs governing bodies and between NGO personnel receiving salaries from foreign donors (A.K., interview, 17 March).

In an urban center, called BISAN Centre for Research \& Development, the internal harmony inside the $\mathrm{BoD}$ and GA is guaranteed by recruiting all members from supporters and friends of the Popular Front for Liberation of Palestine (PFLP). One GA member and a close friend of the former General Manager, and who is not a PFLP supporter, stopped attending GA meetings (KB., interview, 15 March). BISAN works in line with the PFLP vision (JA., interview, 31 March), but the NGO "does not allow PFLP to interfere in its management" (KB., interview, 15 March) although it is not apparent how this can be done when $\mathrm{BoD}$ and staff members are all PFLP supporters. The interviewees further explained that all political

\footnotetext{
${ }^{2}$ PARC was created by the Palestinian People's Party (PPP) in 1980 as a union from several grassroots (A.K., interview, 17 March 2011). Now it is the biggest organization in the West Bank working with women, youth and farmers to protect Palestinian land from confiscation and other occupation measures.
} 
factions, not only the left-leaning ones, use this tactic of creating many linkages among community, NGOs, and political party members (Kafreyat focus group, 19 March). Some cooperate with other community organizations and cooperatives of different political affiliations (Beita case study, 10 May). In extreme cases, participation in $\mathrm{CBO}$ activities is conditioned by potential beneficiaries' acceptance to apply for membership in the political faction.

In refugee camps, PA and political factions do not interfere in CBOs affairs except during BoDs elections because the camps' Popular Committees are actually in charge of all affairs ${ }^{3}$. UNRWA is the major player in service delivery and refugee protection in the camps. Sometimes, UNRWA provides camp-based CBOs some of the funds solicited in the name of Palestinian refugees (El-Amari focus group, 31 May) in the form of project grants. CBOs report directly to UNRWA offices through a computerized system where projectrelated information on funds, activities, beneficiaries' names are entered and stored (MS., interview, 12 April). UNRWA funds small projects and activities that are repetitive and conventional in scope. The refugee population would rather see UNRWA's funding spent on women's education and economic production projects rather than on celebrating women's day and other international occasions (ElAmari focus group, 31 May).

\subsection{Relationship with Local Government}

The results of both surveys indicate that NGOs-local government cooperation ranges between weak to satisfactory, irrespective of the type of organization and locality. About $40 \%$ to $46 \%$ of respondents were less than satisfied with the current relationship. The two groups disagreed on qualifying the exact relationships whether as more than satisfactory as reported by $60 \%$ of NGO managers, or just satisfactory, as indicated by $54 \%$ of staff. None of the staff surveyed said the relationship with local government is actually as good as it should be.

\footnotetext{
${ }^{3}$ Refugee Camps' Popular Committees are PLO structures funded through the PA general budget under PLO budget line.
} 
108 Table 7: Respondents Perceptions of Current NGO-Local Government Relationship

\begin{tabular}{|c|c|c|c|c|c|}
\hline Group & Sample Size & $\begin{array}{l}\text { Weak } \\
(1-2)\end{array}$ & $\begin{array}{l}\text { Satisfactory } \\
(3-4)\end{array}$ & $\begin{array}{l}\text { Good } \\
(5-6)\end{array}$ & Mean \\
\hline $\begin{array}{ll}\text { NGOs } & \text { Top. } \\
\text { Management } & \\
\end{array}$ & 40 & $40 \%$ & $37.5 \%$ & 22.5 & $2.83 \%$ \\
\hline Staff & 100 & $46 \%$ & $54 \%$ & $0 \%$ & $2.96 \%$ \\
\hline
\end{tabular}

Interviews with members in $\mathrm{CBO}$ s and local councils' ${ }^{24}$ indicate that municipalities and local councils depend on external funding in the same manner as NGOs. The majority of local $\mathrm{CBOs}$ require facilitation, authorization and financial support from their local councils in order to operate successfully. Nevertheless, about $40 \%$ of the sample described their relationship with local governance as weak even though it is expected to be stronger with official institutions at the local level. Compared to village councils, municipalities are richer, stronger and exercise more power over NGOs and CBOs working within their boundaries (R.El-T., interview, 12 January; M.ElR., interview, 4 April). Often times municipalities are cooperative and allow local $\mathrm{CBO}$ s to take part in needs assessments and strategic planning (R.El-T., interview, 12 January), and sometime they completely disregard local CBOs.

Table 8: NGO-Local Government Relations by Type of Organizations

\begin{tabular}{|l|l|l|l|l|l|l|l|l|}
\hline \multirow{2}{*}{ Type } & \multicolumn{4}{|l|}{ Current Cooperation } & \multicolumn{3}{l|}{ Future Cooperation } \\
\cline { 2 - 9 } & Weak & $\begin{array}{l}\text { Satisfac } \\
\text { tory }\end{array}$ & Good & Total & Weak & $\begin{array}{l}\text { Satisfac } \\
\text { tory }\end{array}$ & Good & Total \\
\hline NGO & 6 & 6 & 5 & 17 & 1 & 7 & 9 & 17 \\
\hline CBO & 10 & 9 & 4 & 23 & 0 & 5 & 18 & 23 \\
\hline Subtotal & $\mathbf{1 6}$ & $\mathbf{1 5}$ & $\mathbf{9}$ & $\mathbf{4 0}$ & $\mathbf{1}$ & $\mathbf{1 2}$ & $\mathbf{2 7}$ & $\mathbf{4 0}$ \\
\hline Advocacy & $\mathbf{3}$ & 3 & 2 & 8 & 0 & 4 & 4 & $\mathbf{8}$ \\
\hline Services & 9 & 10 & 5 & 24 & 0 & 6 & 18 & $\mathbf{2 4}$ \\
\hline Both & 4 & 2 & 2 & 8 & 1 & 2 & 5 & $\mathbf{8}$ \\
\hline Subtotal & $\mathbf{1 6}$ & $\mathbf{1 5}$ & $\mathbf{9}$ & $\mathbf{4 0}$ & $\mathbf{1}$ & $\mathbf{1 2}$ & $\mathbf{2 7}$ & $\mathbf{4 0}$ \\
\hline
\end{tabular}

4 Palestinian local 'governments' or local councils units are include municipalities, villages, project committees and joint service councils. The first two are directly elected administrative units that lack legislative powers or mandate for collection of major taxes. They are financially independent but receive assistance from the PA 'government'. 
It is generally service delivery organizations that are more satisfied with the local governments because the latter are more accepting of local organizations when they provide social or economic services. Such organizations are perceived as less political but important institutions filling in the gaps in PA services at the local level.

\subsection{Relationship within the NGO Sector}

The NGO literature is not the only source of information on NGOs lack of coordination and vision. The interviews revealed a total agreement on this statement among the surveyed managers and staff as well as among the interviewees. In general, NGO staff is inclined to describe this relationship as good (29\%) more than managers (7.5\%). Those in top management are more satisfied with the coordination among NGOs as expressed by $45 \%$ of this group.

Table 9: Respondents' Satisfaction of Coordination in NGO Sector

\begin{tabular}{|l|l|l|l|l|}
\hline Group & Sample & Weak & Satisfactory & Good \\
\hline Top Management & 40 & $47.5 \%$ & $45 \%$ & $7.5 \%$ \\
\hline Staff & 100 & $45 \%$ & $26 \%$ & $29 \%$ \\
\hline
\end{tabular}

Moreover, Table 6.10 below depicts a satisfaction rate lower than $50 \%$ in both NGOs and CBOs. The least satisfied are the mixedgender membership service delivery organizations belonging to the older generation of NGOs. This is somehow expected because this generation was created under occupation therefore is highly political and more competitive with the PA and newer NGOs.

Table 10: Respondents' Perceptions of NGOs Coordination by Type of Organization

\begin{tabular}{|l|l|l|l|l|}
\hline \multirow{2}{*}{ Type of organization } & \multicolumn{4}{|l|}{ Current Coordination } \\
\cline { 2 - 5 } & Weak & Satisfactory & Good & Total \\
\hline NGO & 8 & 8 & 1 & 17 \\
\hline CBO & 11 & 10 & 2 & 23 \\
\hline Subtotal & $\mathbf{1 9}$ & $\mathbf{1 8}$ & $\mathbf{3}$ & $\mathbf{4 0}$ \\
\hline advocacy & 3 & 5 & 0 & 8 \\
\hline Services & 11 & 11 & 2 & 24 \\
\hline Both & 5 & 2 & 1 & 8 \\
\hline Subtotal & $\mathbf{1 9}$ & $\mathbf{1 8}$ & $\mathbf{3}$ & $\mathbf{4 0}$ \\
\hline
\end{tabular}




\begin{tabular}{|l|l|l|l|l|}
\hline Women & 4 & 3 & 1 & 8 \\
\hline Mixed & 12 & 13 & 2 & 27 \\
\hline Men & 3 & 2 & 0 & 5 \\
\hline Subtotal & $\mathbf{1 9}$ & $\mathbf{1 8}$ & $\mathbf{3}$ & $\mathbf{4 0}$ \\
\hline Coalitions & 15 & 10 & 2 & 27 \\
\hline Non-coalition & 4 & 8 & 1 & 13 \\
\hline Subtotal & $\mathbf{1 9}$ & $\mathbf{1 8}$ & $\mathbf{3}$ & $\mathbf{4 0}$ \\
\hline Pre-1990 & 6 & 3 & 0 & 9 \\
\hline $1990-2000$ & 7 & 5 & 1 & 13 \\
\hline $2001-2010$ & 6 & 10 & 2 & 18 \\
\hline Subtotal & $\mathbf{1 9}$ & $\mathbf{1 8}$ & $\mathbf{3}$ & $\mathbf{4 0}$ \\
\hline
\end{tabular}

Advocacy organizations however coordinate less frequently although advocacy requires networking and collective efforts to produce tangible results. The Pre-Madrid generation and men-only organizations showed the lowest mean score of 1.89 . However, most optimistic responses came from the newest mixed- gender membership NGOs working throughout the West Bank with a medium budget of US $\$ 100,000-500,000$ yet without strategic planning.

The sample organizations also pointed out to low cooperation among local CBOs, often times restricted to the implementation of specific projects only when joint activities are built-in project plans (focus group results). However, NGO-CBO coordination depends on their political affiliations and personal relationship. For example, "cooperatives have absolute support and funding from PARC, so farmers groups do not work with other organizations" (Beit Rima focus group, 4 April).

It is evident then that money and politics shape NGOs relationship with their stakeholders. Coordination is lacking within the NGOs community itself while NGO-donor relationship is the strongest. NGOs relationship with political parties and local governments ranges from weak to satisfactory depending on the NGO size and mandate. However, small CBOs need official support from local councils to access funding or implement joint projects while large NGOs can do without municipal support. Nevertheless NGOs-PA relationship remains the most contentious so that NGOs comply with the legal minimums but secretly wish for a transfer of NGOs oversight from the MoI to line ministries. 


\section{NGOs Accountabilities}

Some researchers believe that the NGO community in general lacks internal and external accountability. NGOs internal governance structures are also weak which poses serious challenges to civil society around the world. This is particularly true for the Palestinian society as it has grown rapidly in volume after Oslo Accords (Kim, 2003), and in reliance on foreign donations (DeVoir \& Tartir, 2009). Given the size of the civil society sector in the oPt, the demise of Palestinian NGOs is understandably predictable in case foreign aid dries up without any other alternative source of support to NGOs.

Researchers focus more on examining the nature of donor-NGO relationship; and NGOs accountability to donors. However, there is a limited focus on NGOs accountability towards the public (Kilby, 2004). Literature also has examined NGOs accountability towards the government, (i.e. the PA in the West Bank), from a strictly management point of view (Al-Moaqat, 2007) neglecting that it is equally important to investigate accountability not only as a mechanism or a tool, but also as a reflection of decision-making processes that must be considered in all policy-making phases up to implementation stage (Abdalhadi, 2004; Jad, 2003, Samara, 2001). However, few or no studies have explored public accountability in terms of NGOs adherence to the Palestinian national goals.

The next sections investigate the stakeholders that NGO should be, in theory and practice, accountable to and explore sources and types of accountability with each stakeholder. The section looks at the issue of 'independence' or 'autonomy', mistakenly construed by NGOs as a synonym of 'accountability-free' or as a justification to intentionally reduce or evade their accountability obligations towards its stakeholders. In the case of Palestinian NGOs, organizational independence is a contested concept simply because NGOs accountability and autonomy are not mutually exclusive. The NGO autonomy status endowed by the law refers only to 'interference from public authorities in NGOs affairs' rather than relieving NGOs of all sorts of accountability obligations. The section further explores whether the civil society sector needs a unified model of accountability because of: (a) wide range organizations covered by this 
182 term, (b) the impact of NGOs dependence on foreign funding seen as a major obstacle for them to enhance their accountability to the public in particular.

\subsection{Definition, Source and Forms of NGO Accountability}

Accountability is a relatively new term with multiple facets and aspects particularly when applied to the third sector. The concept denotes both ethics and governance but there are a number of definitions in circulation, each highlighting one or more of its aspects.

The term 'accountability' indicates "the means by which individuals and organizations report to a recognized authority or authorities, and are held responsible for their actions" (Fox \& Brown cited in Ebrahim, 2003, p. 813). In this definition, the principle of accountability is simplified to denote transparency and the right to access information. Accountability is also defined as a "process of holding actors responsible for their actions" (Fox \& Brown, cited in Ebrahim, 2003, p. 814) and about "being 'held responsible' by others and 'taking responsibility' for oneself" (Cornwall et al. cited in Ebrahim, 2003, p. 814).

It is difficult to ignore the vagueness and the legalistic nature of the last two definitions. The Palestinian law of 2000 echoes some of the legal focus in its emphasis of the NGO's internal structure, e.g. NGO founding committee, GA, and $\mathrm{BoD}$, while not holding $\mathrm{NGO}$ leaders responsible before the law (Al-Moaqat, 2007). Although the above definitions of accountability are limited to legal aspects and mechanisms of reporting to authorities, other definitions reduce the concept even further to cover only NGOs finances. It is noticeable that the literature disagrees on the scope of NGOs accountability except with regard to the financial performance which ultimately means "how NGOs spend their money" (Tandon, n.d.). Despite such narrow scopes, accountability still brings important value connotations as a 'moral principle' (Gray et al., 2006) that cannot be overlooked while discussing NGOs accountability in relation to national goals. 


\subsection{External Accountability}

Each organization is theoretically accountable to multiple stakeholders ${ }^{5}$ that enjoy certain rights and powers over the organization's existence and operation. There are two distinct major stakeholder groups to analyze in terms of their relationships to an NGO.

NGOs external stakeholders are usually the following entities: a- NGO service users / target groups

b- NGO community / local community and their components c- Public authority (e.g. PA)

d- Donors / financial supporters

It is argued that with the above external groups, there are formal systems of NGO accountability involving formal tools. According to Ebrahim:

There are five broad mechanisms of accountability: reports and disclosure statements, performance assessments and evaluations, participation, self-regulation, and social audit. Each mechanism, distinguished as either a 'tool' or a 'process,' is analyzed along three dimensions of accountability: upward-downward, internal-external, and functional-strategic. It is observed that accountability in practice has emphasized 'upward' and 'external' accountability to donors while 'downward' and 'internal' mechanisms remain comparatively underdeveloped. Moreover, NGOs and funders have focused primarily on short-term 'functional' accountability responses at the expense of longer-term 'strategic' processes necessary for lasting social and political change. Key policy implications for NGOs and donors are discussed (Ebrahim, 2003, p. 1).

However, because NGOs are non-profit seeking yet with structures close to private firms, 'accountability' has accounting implications

\footnotetext{
${ }^{5}$ Stakeholders are not necessarily in sync with one another but may diverge substantially in terms of goals, agendas and relationships to one another. Based on liberal management, there is a premise that conflicts among stakeholders exist but somehow can be resolved. The business school of management suggests that stakeholders can be conflicting but there is a possibility to reach a certain (winwin scenario for all partied involved).
} 
184 much like the business sector itself (Fries cited in Gray et al., 2006), the concept carries two implications on the NGOs:

First, individuals in control of NGO funds (managers and donors) may well be quite distinct from those who receive/benefit from the service (clients or beneficiaries). Typically, there is no direct means by which beneficiaries can enforce accountability upon donors and managers especially when the $\mathrm{NGO}$ is not a membership-based organization.

Second, as not-for-profit, NGOs have no simple system of performance equivalent to the profit/loss measure used in private sector. In profit-oriented organizations, financial analysis and measurement refer to financial statements and dominate all assessments of organizational performance and accountability. While the measurement argument is true, it is possible to define few mechanisms (e.g. those identified by Ebrahim above) through which accountability to stakeholders can be enhanced.

\subsection{Accountability Dilemma in Palestinian Context}

Before embarking on a detailed discussion of the study's accountability findings, I shall present the next table which provides a snapshot of the prevailing NGOs perceptions towards their stakeholders. On a scale of (1) to (7), 1 being the lowest, table 6.12 presents respondents' ranking of the importance of stakeholders to their own organizations and the entire NGO sector. The table collapse responses given by the surveyed NGOs management and staff in order to show the differences in their outlook. The study assumption is that managers are more likely to play it safe and reflect the optimal rather than the actual practices. Compared to their staff, mangers would be more concerned with showing least attachment to donors and a higher level of adherence to national goals.

Table 6.11: Accountability in own NGOs Vs. NGO Sector, by Order of Importance

\begin{tabular}{|l|l|l|l|}
\hline \multirow{2}{*}{ NGO Accountability } & Own NGO & NGO Sector \\
\cline { 2 - 4 } & $\begin{array}{l}\text { Mgt } \\
\text { Perceptions }\end{array}$ & $\begin{array}{l}\text { Mgt } \\
\text { Perceptions }\end{array}$ & $\begin{array}{l}\text { Staff } \\
\text { Perceptions }\end{array}$ \\
\hline $\begin{array}{l}\text { Towards the Palestinian } \\
\text { public \& local communities }\end{array}$ & 1 & 2 & 2 \\
\hline
\end{tabular}




\begin{tabular}{|l|l|l|l|}
\hline $\begin{array}{l}\text { Towards the Palestinian } \\
\text { national goals }\end{array}$ & 2 & 3 & 3 \\
\hline $\begin{array}{l}\text { Towards NGO board of } \\
\text { directors }\end{array}$ & 3 & NA & NA \\
\hline $\begin{array}{l}\text { Towards the Palestinian } \\
\text { Authority }\end{array}$ & 4 & 4 & 4 \\
\hline Towards the NGO donors & 5 & 1 & 1 \\
\hline Towards the NGO sector & 6 & NA & NA \\
\hline $\begin{array}{l}\text { Towards the political } \\
\text { parties/ factions }\end{array}$ & 7 & NA & NA \\
\hline $\begin{array}{l}\text { Towards Palestinian future } \\
\text { generations }\end{array}$ & NA & 5 & 5 \\
\hline
\end{tabular}

NA indicates that this question was not directed to that group. 1 indicates the most important stakeholder while 7 the less important. Out of 40 Top Mgt. official 37 and 100 staff answered to the question about their own organizations.

The above table confirms many of the study's initial assumptions. Managers stated that their utmost priority is being accountable to the public and Palestinian communities. Their staffs completely disagree: their first accountability is in fact directed to their own donors, much like all other organizations, followed by accountability to the public. Both groups ranked the PA as the fourth important stakeholder that NGOs are accountable to while accountability to political factions is seen as the least important by the NGOs management unlike the staff who said NGOs are least accountable to Palestinian future generations.

In reality, Palestinian NGOs perception of accountability is influenced by the 'reporting to donor mentality' and by their relationship to their 'beneficiaries-clients'. Given the NGOs lack of community identity, it is harder to ensure their accountability to the Palestinian society since they are seen as being 'hijacked' by donors' agendas and funding used to further individual interests. Therefore, they only hold themselves accountable to no other stakeholder but the most essential and powerful of all: their donors.

\subsection{Mentality of Accountability}

NGOs model of interaction with the recipients of their services can be described as 'business like' modelling the relationship typically 
186 found between a service provider and user. In reality, NGOs service users do not even rise to the client status per se. Obviously, this constitutes an important element of the NGOs accountability dilemma, especially towards the public. The mainstream model can be summarized as follows: NGO's role is to solicit donor funds then provide services to the public freely or at a reduced cost than provided by the private sector. The public is therefore relegated to the status of passive 'recipients', 'service users' who should be thankful to the NGO's generosity but have no rights to exercise over the services delivered to them, question their relevance or planning or even monitor the quality and process of their delivery. In the NGO's mind, the service provider has the 'upper hand', compared to the powerless citizens (DW., interview, 22 April).

Because of the aforementioned mentality, NGOs prepare and address their reports to other audience rather than the service users. Almost always written in foreign languages, NGO reports provide donors with as much details demanded by them. Major publications and media stories are also done in the same manner. Compared to their interaction with the public, the research community, or even their own $\mathrm{BoD}$ and GA members, NGO officials designate far more time and effort to meet their funders. Unlike donors, researchers and GA members struggle to gain access to NGO information (MD., interview, 16 March).

The widespread reporting mentality entails that NGOs practice oneway accountability which in turn highlights the power relationship between an NGO and its various stakeholders. NGOs are more likely to cooperate with parties that have power over them, be it financial or regulatory, impossible for the NGO to escape. If left to their own choosing, NGOs seem unwilling to report to any stakeholder unless there is a reason that tips the balance in favour of this or that stakeholder (MD., interview, 16 March).

NGOs face challenges at the very heart of their existence: their representation of the social groups, issues and needs. In the public eye, NGOs collectively are seen as bogged down with immoral, illegal and essentially corrupt practices. NGOs choice is akin to voluntary blindness and the ensuing confusion regarding NGO accountability, legitimacy, and independence. 
Palestinian NGOs frequently claim they enjoy relative independence in managing their activities and projects (Bargouthi cited in Hilal, 2006). It is doubtful, however, that this is the case. In reality, some NGOs are affiliated to PA or political parties that manipulate their activities to benefit such affiliations. Moreover, donors' interference is visible in dictating NGOs agendas, programs, and projects in their implementation. Donors attach a long list of political conditionality prior to and during receipt of funding (AMAN, 2009). In addition, donors and the PA are encouraged the formation of certain types of NGOs to operate mainly in the West Bank (Bargouthi cited in Daifallah, 2006; Abu El-Zolf in PJW, 2008; HI., interview, 9 April; A.K., interview, $17 \mathrm{March}$ ). This begs a question with regard to the source of the NGO legitimacy should be solely bestowed by the grassroots and the Palestinian public (Awashra, 2011).

Finally, one observation needs to be made with regard to internal accountability, since the majority of experienced and influential Palestinian NGOs with political affiliations. This sounds like a legitimate consideration given the fact that the NGO law is silent on the accountability of mass arms of political parties although they are also registered as non-profit organizations under the same law. There is a dearth of information with regard to this important group of organizations that are undoubtedly influential at the local and national levels but they march to a different tune than the nonpolitically affiliated sisters.

\subsection{Accountability to the Palestinian Public}

Legal and the idealistic views of community action presuppose that NGOs exist to serve the public good (Najim, 1996; Muhsin, 2006 ) despite the awareness of NGOs seeking narrow, individual interests more than political parties. Self-serving as they are, they are bound to adopt up-ward accountability models particularly towards donors not the public (Bobbio cited in Bishara, 1996). As indicated in table 6.13, half of the NGOs Top. Mgt. officials (55\%) surveyed assigned the highest accountability to the public then to the local community through incorporation of community needs in NGOs programs $(52.5 \%)$. The third highest, from a management point of view, is 
NGO transparency and access to information (47.5\%) while public participation in decision making comes in the last place with (22.5\%).

Table 12: Perceptions Top Mgt. and Staff about NGO Accountability to the Public

\begin{tabular}{|c|c|c|c|c|}
\hline Statement & Group & Weak & Satisfactory & Good \\
\hline \multirow{2}{*}{$\begin{array}{l}\text { Inclusion of public needs in } \\
\text { NGOs projects }\end{array}$} & Mgt & $47.5 \%$ & $42.5 \%$ & $10 \%$ \\
\hline & Staff & $72 \%$ & $22 \%$ & $6 \%$ \\
\hline \multirow{2}{*}{$\begin{array}{l}\text { Public participation in } \\
\text { NGOs decision making }\end{array}$} & Mgt & $77.5 \%$ & $17.5 \%$ & $5 \%$ \\
\hline & Staff & $99 \%$ & $1 \%$ & $0 \%$ \\
\hline \multirow{2}{*}{$\begin{array}{l}\text { NGOs accountability to } \\
\text { public/local community }\end{array}$} & Mgt & $45 \%$ & $35 \%$ & $20 \%$ \\
\hline & Staff & $25 \%$ & $73 \%$ & $2 \%$ \\
\hline \multirow{2}{*}{$\begin{array}{l}\text { Public access to NGO } \\
\text { information from }\end{array}$} & Mgt & $52.5 \%$ & $27.5 \%$ & $20 \%$ \\
\hline & Staff & $58 \%$ & $40 \%$ & $2 \%$ \\
\hline \multirow[t]{2}{*}{ NGOs transparency } & Mgt & $52.5 \%$ & $30 \%$ & $17.5 \%$ \\
\hline & Staff & $48 \%$ & $50 \%$ & $2 \%$ \\
\hline
\end{tabular}

Overall, the combined percentages of satisfactory and good performance are very close in both respondent groups. Both agreed that the weakest of $\mathrm{NGO}$ performance occurs in participatory decision-making (77.5\% of managers and $99 \%$ of staff) and in NGOs incorporation of public needs in NGO projects (47.5 of manager and $72 \%$ of staff) transparency ( 52.55 of managers and $48 \%$ of staff) and public access to NGO information $(52.5 \%$ of managers and $58 \%$ of staff). This has much to do with change in NGOs goals and programs to fit more with donors' agendas. NGOs usually allow or tolerate some public participation lending even more support to the accusation of NGOs being strategically more accountable to donors than to local communities themselves (Najim, 1996, p. 351).

In other words, NGO staffs are less satisfied than their managers of NGO accountability in almost all the statements. In contrast, very few staff believe that their organizations are doing a stellar job so that only $2-20 \%$ describes the performance of their NGOs as 'good' on almost all aspect of accountability. As indicated in table 6.14 NGO managers are also more convinced than $\mathrm{CBO}$ managers of their accountability. They are either more hesitant to admit the low accountability levels or do not wish for the enforcement of any more accountability. 
Table 6.13: Perception of Top. Mgt. official of NGOs Accountability to Public

\begin{tabular}{|l|l|l|l|l|l|}
\hline \multirow{2}{*}{ Type } & $\begin{array}{l}\text { Total } \\
\text { Respond } \\
\text { ents }\end{array}$ & \multicolumn{5}{|l|}{ Current Accountability } \\
\cline { 3 - 6 } & 17 & Weak & $\%$ & $\begin{array}{l}\text { Satisfactor } \\
\text { y-good }\end{array}$ & $\%$ \\
\hline NGO & 5 & $29.41 \%$ & 12 & $70.59 \%$ \\
\hline CBO & 23 & 13 & $56.52 \%$ & 10 & $43.48 \%$ \\
\hline Subtotal & $\mathbf{4 0}$ & $\mathbf{1 8}$ & $\mathbf{4 5} \%$ & $\mathbf{2 2}$ & $\mathbf{5 5 \%}$ \\
\hline Advocacy & 8 & 3 & $37.5 \%$ & 5 & $62.5 \%$ \\
\hline Services & 24 & 12 & $50 \%$ & 12 & $50 \%$ \\
\hline Both & 8 & 3 & $37.5 \%$ & 5 & $62.5 \%$ \\
\hline Subtotal & $\mathbf{4 0}$ & $\mathbf{1 8}$ & $\mathbf{4 5} \%$ & $\mathbf{2 2}$ & $55 \%$ \\
\hline Women & 8 & 5 & $62.5 \%$ & 3 & $37.5 \%$ \\
\hline Mixed & 27 & 10 & $37.04 \%$ & 17 & 62.96 \\
\hline Men & 5 & 3 & $60 \%$ & 2 & $40 \%$ \\
\hline Subtotal & $\mathbf{4 0}$ & $\mathbf{1 8}$ & $\mathbf{4 5 \%}$ & $\mathbf{2 2}$ & $\mathbf{5 5 \%}$ \\
\hline$<$ US\$ 100,000 & 17 & 10 & $58.82 \%$ & 7 & $41.18 \%$ \\
\hline $100-500,000$ & 9 & 4 & $44.44 \%$ & 5 & $55.56 \%$ \\
\hline$>0.5$ million & 7 & 2 & $28.57 \%$ & 5 & $71.43 \%$ \\
\hline Subtotal & $\mathbf{3 3}$ & $\mathbf{1 6}$ & & $\mathbf{1 7}$ & \\
\hline Strategic plans & 17 & 7 & $41.20 \%$ & 10 & $58.80 \%$ \\
\hline No strategic plans & 23 & 11 & $47.82 \%$ & 12 & $52.18 \%$ \\
\hline Subtotal & 40 & 18 & & 22 & \\
\hline West Bank & 13 & 4 & $30.76 \%$ & 9 & $69.24 \%$ \\
\hline District & 10 & 3 & $30 \%$ & 7 & $70 \%$ \\
\hline Local & 17 & 11 & $64.7 \%$ & 6 & $35.3 \%$ \\
\hline Subtotal & 40 & 18 & $45 \%$ & 22 & $55 \%$ \\
\hline
\end{tabular}

Furthermore, table 6.14 indicates that respondents from Oslo generation and service provision organizations feel that NGOs show weak accountability to the public more than the newer generations created during the past 20 years. About two thirds of managers of advocacy and mixed gender membership NGOs believe their organizations have satisfactory or good accountability practices. In addition, managers of small, locally-based organizations operating on an annual budget of less than USD 100,000 provided the argent percentage of 'weak' responses indicating there are least convinced of the overall level of NGO accountability to the public.

With regard to information dissemination, the study found some NGOs and fewer CBOs in the sample operating websites but limit their contents to the basic information about their missions, goals, 
10 projects and occasionally organizational structures. Only 5 out of 20 organizations publish brief financial statements with disclosing any detail on for example the salaries as a percentage of the NGOs operational costs, especially the remuneration of the top management ${ }^{6}$. Both public and PA believe that NGO staff receive high salaries and several proposed suggested the promulgation of NGO bylaw or act similar to the civil service law to delineate NGOs salary scales and remuneration systems (RN., interview, 25 April). Furthermore, it is customary for NGOs to upload their publicity materials and sometime annual reports intended for publication; while solid information such as needs assessment, strategic plans, project documents and evaluation reports are kept confidential and can only be accessed upon request by those with the right personal connections (e.g. researchers).

The public seem to have less access to NGOs information than to CBOs despite the availability of knowhow and information dissemination methods in the NGOs. Table 6.15 indicates that this level of secrecy seems to be practiced by the older, pre-Oslo generation of politically-affiliated mass organizations while the 1990s generation is doing relatively a better job. This might be explained by the donors' visibility obligations and funding conditions that can make information dissemination a must or leave it to the discretion of the NGO itself.

\section{Table 14: Public Access to NGO information}

\begin{tabular}{|l|l|l|l|l|}
\hline Type & Weak & Satisfactory & Good & Total \\
\hline NGO & 10 & 3 & 4 & 17 \\
\hline CBO & 11 & 8 & 4 & 23 \\
\hline Subtotal & 21 & 11 & 8 & 40 \\
\hline Before 1990 & 3 & 5 & 1 & 9 \\
\hline $1991-2000$ & 8 & 0 & 5 & 13 \\
\hline $2001-2010$ & 10 & 6 & 2 & 18 \\
\hline Subtotal & 21 & 11 & 8 & 40 \\
\hline
\end{tabular}

\footnotetext{
${ }^{6}$ One NGO manager I interviewed suggested that organizations should disclose their detailed financial data to enhance their accountability and transparency. However the same interviewee refused to provide the researcher with the requested financial information.
} 
In the case of $\mathrm{CBOs}$ in villages and refugee camps, it is more likely that the organization's staff, general assembly and BoD members come from the same local community, which translates into direct interaction with the public. The fact that local communities are small in size and have closely-knit social relationships so people are likely to know each other guarantees a formal type of downward accountability particularly in terms of inclusion of local needs in CBO programs. For example, El-Amari Women's Centre works on poverty reduction, income-generation, vocational training and political empowerment of residents, particularly among women in addition to promoting refugees' right to return among Palestinian communities, donor agencies and diplomatic missions (El-Amari focus group, 31 May).

NGOs in major cities come at the other end of accountability spectrum, raising people's doubt and criticism for their "fancy offices, cars, inflated salaries and foreign funding" (SM., interview, 18 December 2010). Think-tanks, advocacy, women and youth NGOs are singled out for criticism more than charitable societies and CBOs operating with local funds. This may explain partly why the grassroots and $\mathrm{CBO}$ are seen more accountable to the public while foreign funding may increase the scope of service provided, they have the downside of raising questions about their accountability to donors on the account of accountability to the local communities and the public in general (Hulme \& Edwards cited in Kamat, 2004).

\subsection{Accountability to Palestinian Authority}

According to table $6.16,80 \%$ of NGO staff surveyed and $48 \%$ of the top management feel that NGOs accountability to the PA is weak. Could it be a case of NGOs trying to pretend to be less submissive to the $\mathrm{PA}^{7}$ than they actually are or would it entail a different form of accountability that NGOs need to practice vis-à-vis the PA? This has to be seen!

\footnotetext{
${ }^{7}$ A public survey conducted by AMAN in 2005 found that the Palestinian public believe that 'the PA government should fulfil its accountability roles'. About $61 \%$ of West Bank respondents and 65\% in the Gaza Strip said that the PA is not doing that role in the right manner.
} 


\section{Table 15: Respondents' Perceptions of NGOs Accountability to the} PA

\begin{tabular}{|l|l|l|l|}
\hline Group & Weak & Satisfactory & Good \\
\hline Top Management & $47.5 \%$ & $32.5 \%$ & 20 \\
\hline Staff & 80 & 20 & $0 \%$ \\
\hline
\end{tabular}

Upon closer look, the data in both surveys suggests that the new generation of organizations are more accountable to the PA, probably due to their relative nascence as they were born after the passage of Law No (1) of 2000 and during an era that engulfed the non-profit in many battles with the PA and de facto Hamas authority in the Gaza Strip.

Table 16: Top Managers' Perceptions of NGOs Accountability to the PA

\begin{tabular}{|l|l|l|l|l|}
\hline Type & Weak & Satisfactory & Good & Total \\
\hline Before 1990 & 5 & 2 & 2 & 9 \\
\hline $1991-2000$ & 7 & 3 & 3 & 13 \\
\hline $2001-2010$ & 7 & 8 & 3 & 18 \\
\hline Subtotal & $\mathbf{1 9}$ & $\mathbf{1 3}$ & $\mathbf{8}$ & $\mathbf{4 0}$ \\
\hline NGO & 8 & 5 & 4 & 17 \\
\hline CBO & 11 & 8 & 4 & 23 \\
\hline Subtotal & $\mathbf{1 9}$ & $\mathbf{1 3}$ & $\mathbf{8}$ & $\mathbf{4 0}$ \\
\hline Advocacy & 2 & 4 & 2 & 8 \\
\hline Services & 11 & 8 & 5 & 24 \\
\hline Both & 6 & 1 & 1 & 8 \\
\hline Subtotal & $\mathbf{1 9}$ & $\mathbf{1 3}$ & $\mathbf{8}$ & $\mathbf{4 0}$ \\
\hline
\end{tabular}

One way of accountability to the PA can be found in the extent of NGOs participation in PA planning and adherence to the national plans in their programs. During the interviews, it became clear that NGOs are unaware of $\mathrm{PA}$ plans ${ }^{8}$, lack interest in their

\footnotetext{
${ }^{8}$ For example, the director of a national agricultural NGO is unaware of the national plans developed for the sector by the Ministry of Agriculture. Almost every PA ministry has its five-year strategic plans, and sometime there are crosssectoral plans such as the cross-sectoral plan for local governance developed in 2010 through USAID support in participation with the ministries of Finance, Education, Health, Public Works, industry, Economy and Planning and in addition to Water, Environment and Energy Authorities and the Association of Palestinian Local Authorities (APLA). The Ministry of Planning routinely develops short
} 
implementation or disagree with the PA in their directions and technical content (El-Z., interview, 17 January; HA., 10 February). Working within the framework of PA priorities can also indicate loss of NGO freedom and independence or that gearing NGOs activities towards supporting the interest of the ruling party (i.e Fateh movement) (ZY., interview, 10 March; RN., interview, 25 April; A.J., interview, $27 \mathrm{March})$. To some organizations, PA plans offer NGOs potential funding opportunities from donor agencies involved in PA planning (KB., interview, 15 March). Instead of adopting a follower stance, as the PA prefers, NGO leaders ask for full and equal partnership with the PA and have a real say in the decision-making over PA planning and the national and sectoral levels (ZN., interview, 15 February; KH., interview, 26 April). Other NGOs, such as the Welfare Association, do not oppose nor follow PA planning but target sectors that not covered by the PA and major donors (DW., interview, 22 April). On the other hand, the PA shares the popular view that urban NGOs, mainly those with left orientations, are essentially accountable to their political factions (RN., interview, 25 April) and donors (ZEY., interview, 3 March) and insensitive to public needs (FRE., interview, 30 April). Some PA officers think NGOs serve donors' agendas and secretly strive to weaken the PA and are awaiting the opportunity to take over in due time (ZEY., interview, 3 March).

\subsection{Accountability to the NGO Sector}

Unsurprisingly, the study findings show NGOs accountability to the NGO sector is also weak, occupying the second lowest place after accountability to political parties. Some interviewees explained this weakness by the absence of a unified vision, competition over funding, political disagreements among NGO leaders, and a generally non-existent collaboration unless warranted by a common interest. Competition over NGO funding weakens their collective accountability and caused conflicts that damaged the reputation of the non-profit sector before donors and the public (T.NA.,

term and long term planning ranging between 3-15 years, with support from the World Bank or other agencies such as the UNICEF that backs up the national strategy for Palestinian children. 
19uversation, 22 February; SA., interview, 1 February, A.K., interview, 17 March).

At the other end, organizations rarely adopt a unified approach or position to NGO affairs unless promoted by an immediate goal or sense of solidarity against measures undertaken by the PA or security forces. Currently umbrella associations and unions seldom do anything to enhance the sector's accountability to the public or at least to the non-profit sector. PNGO, the most expansive of network, has long fallen victim to political rivalries between factions that severely hindered its ability to function as a real umbrella or platform (HA., interview, 10 February; ET., interview, 15 March; A.J., interview, $27 \mathrm{March}$ ).

On other occasions, relationships fluctuate between urban-based and local organizations depending on who needs whom or unless pressured by donors occasionally funding joint projects. In few cases, donors insisting on NGO-CBO cooperation or design program based on NGO-CBO partnership so that the NGOs can meet donors' requirements and 'mentor' $\mathrm{CBOs}$ to develop their institutional capacities and systems (e.g. planning, recruitment, procurement, accounting, etc.) in parallel with activity implementation so that the $\mathrm{CBO}$ systems become more in line with their contractual obligations with the donor (ER., interview, 15 December).

\subsection{NGOs Accountability to Political Parties}

At first, I hesitated to include any questions on political parties in the surveys, preferring to discuss any pertinent issue directly with the interviewees. The piloting showed that these questions can be directly addressed to the survey respondents. The findings indicate that NGOs accountability towards political factions is not only weak but in fact the weakest of all NGO accountability to all stakeholders. In fact managers gave the political parties the seventh and lowest place in terms of importance as a stakeholder they should be accountable to (see table 6.12). Moreover, only $37.4 \%$ of staff stated that their relationships with political parties are satisfactory or good compared to $52 \%$ of surveyed managers (see table 6.2 ).

In the survey, few NGOs stated that 'NGOs refrain from engagement in politics or adopting a political agenda' as one of the sector's 
priorities (see table 5.19). The NGOs are split on this issue. On one hand, one view believes that while NGOs should not be accountable to political parties and factions, yet it is possible for NGOs to work along a political or factional vision without being involved directly in politics or allowing factional interests to infringe on their management. Another view stresses the general feeling that "it is far better for the Palestinian public if NGOs are led by the political parties instead of being solely controlled by donors and the current NGO elites" (SAR., interview, 26 April). However, the last statement should not be seen a case of favouring political factions over NGOs but a matter of caution and a damage-control strategy opting for the selection of the least bad scenario (i.e. factions/parties vs. donors/elites). Even though, it is felt that for it would be highly critical to protect the NGOs from politics in order for the non-profit sector to become accountable to next generation and to national agenda (Shawa, 2000).

\subsection{NGOs Accountability to Donors}

Donors differ in the requirements they demand from their 'partner' organizations before and after a grant award is made. After the fund is offered, donors generally require periodic reporting, financial and narrative, visibility, separate bank account for the funded project and public acknowledgment of donor funding in newspaper, publicity materials and events. Foreign donors expect that NGOs and CBOs avoid using their funds to work against the interests of the Israeli occupation or not be involved in such activities at all.

In the field, participants expressed various understandings of the issue of donors' impact on Palestinian politics. At the national level, donors in various ways do influence the PA and its official institutions flowing down to local councils. Also national NGOs are more susceptible to donor influence but donor-funded projects' themselves had no direct impact on the results of Palestinian national or local elections (Kafreyat focus group, 19 March).

Generally, Palestinian NGOs are consistently accountable to their donors. Interviewees indicated that accountability to donors is strongest and more regular and approximately $70 \%$ of surveyed staff and top managers described it as good and/or satisfactory. The 
106 comparative percentages in table 6.18 show that $\mathrm{CBOs}$ are weaker than NGOs in being accountable to their donors, probably because $\mathrm{CBOs}$ have far few foreign donors in the first place and operate on a small scale that leave less opportunity for mismanagement.

Table 6.17: Perceptions of NGOs Accountability to Donors by Surveyed Group

\begin{tabular}{|l|l|l|l|}
\hline Group & Weak & Satisfactory & Good \\
\hline Top management & $30 \%$ & $25 \%$ & $45 \%$ \\
\hline Staff & $26.3 \%$ & $12.1 \%$ & $61.6 \%$ \\
\hline
\end{tabular}

While the percentages do not indicate a significant difference between the groups, the results become apparent when the results are cross-tabulated with the other six organizational types. In terms of NGO generation, the pre-Oslo organizations are more satisfied with their accountably to donor, e.g. political factions, PLO support, European solidarity funds, etc., although it is not clear how these donors enforce such accountability because of the overtly political nature of these generation of oPt organizations. By comparison, advocacy organizations are believed to be more adhering to donor accountability than their service delivery or combined-mandate sisters. Probably this is directly related to the availability of systems, funding and other capacities within the advocacy subsector compared to the other organizations.

Table 6.18: Perceptions of NGOs Accountability to Donors by Type of Organization

\begin{tabular}{|l|l|l|l|l|}
\hline Type & Weak & Satisfactory & Good & Total \\
\hline NGO & 2 & 2 & 13 & 17 \\
\hline CBO & 10 & 8 & 5 & 23 \\
\hline Subtotal & $\mathbf{1 2}$ & $\mathbf{1 0}$ & $\mathbf{1 8}$ & $\mathbf{4 0}$ \\
\hline Before 1990 & 2 & 2 & 5 & 9 \\
\hline $1991-2000$ & 3 & 2 & 8 & 13 \\
\hline $2001-2010$ & 7 & 6 & 5 & 18 \\
\hline Subtotal & $\mathbf{1 2}$ & $\mathbf{1 0}$ & $\mathbf{1 8}$ & $\mathbf{4 0}$ \\
\hline Advocacy & 1 & 1 & 6 & 8 \\
\hline Services & 9 & 8 & 7 & 24 \\
\hline Combined & 2 & 1 & 5 & 8 \\
\hline Subtotal & $\mathbf{1 2}$ & $\mathbf{1 0}$ & $\mathbf{1 8}$ & $\mathbf{4 0}$ \\
\hline
\end{tabular}


Finally, donor agencies and INGOs rarely demonstrate accountability to their local partners despite the fact that the majority of partner $\mathrm{NGOs}$ are selected on the basis of changeable criteria and/or personal connections. Donors accountability requirements of NGOs can be too bureaucratic, selective; ad hoc, extensive or sketchy and their enforcement subjective given their history of relationship with the organizations in question. Donors are completely aware of NGOs needs for improved internal governance; leaderships, systems and practices necessary to strengthen their accountability practices. Yet donors fail to recognize that they too are in need for such improvements themselves, at least to be less controlling, make their own decision-making more transparent and less top-down while try to build a relationship with fund recipient NGOs on equal footing.

\subsection{Accountability to Future Generation and National Goals}

NGOs accountability to national goals and future generations also tend to be weak as reported by $43 \%$ to $48 \%$ of surveyed managers and $55 \%$ to $58 \%$ of surveyed staff. Table 6.20 also points out that staffs were the most self-critical of respondents with $58 \%$ stating that this accountability is indeed less than satisfactory to them. Managers are either satisfied or unhappy about their performance. It is however, interesting to see from the percentages that respondents seem to equate national goals with the interests of Palestinian future generations. This is indeed a very political perception and a new spin on the concept of sustainability unique to the organizations in the oPt. It is possible to infer that, under occupation, politics is the major determiner of the future of Palestinian people than, say, sustainable development or sustainable natural resources.

Table 19: NGOs Accountability to National Goals\& Future Generations by Surveyed Group

\begin{tabular}{|l|l|l|l|l|}
\hline Statement & Group & Weak & Satisfactory & Good \\
\hline Accountability towards & Mgt. & $42.5 \%$ & $37.5 \%$ & $20 \%$ \\
\cline { 2 - 5 } Palestinian national goals & Staff & $58 \%$ & $32 \%$ & $10 \%$ \\
\hline $\begin{array}{l}\text { Accountability towards } \\
\text { future generations }\end{array}$ & Mgt. & $47.5 \%$ & $37.5 \%$ & $15 \%$ \\
\cline { 2 - 5 } & Staff & $55 \%$ & $45 \%$ & $0 \%$ \\
\hline
\end{tabular}


Moreover, Table 6.21 reveals that in terms of NGO generations, the politically affiliated mass organizations of the 1970s and 1980s are found to be least accountable as stated by $77 \%$ of this subsector who described this accountability as weak. This contradicts the assumption or popular view that the earlier, pre-Oslo generation is by default more attuned to national goals and struggle because of their participation in popular resistance and voluntary community action for decades before the post-Oslo generations were sprung. Interestingly, about $57.5 \%$ of urban $\mathrm{NGOs}$ and $35 \%$ of $\mathrm{CBOs}$ describe their accountability as satisfactory and/or good. Similarly, advocacy organizations seem equally divided $(50 \%)$ between those who believe in their responsible national and future orientation and those who do not. About $88 \%$ of institutions with a combined advocacy and service delivery mandate are the most satisfied with their performance compared to $41 \%$ of service-only organizations. This may be explained by NGOs tendency to run a mixture of services, advocacy and relief programs, all of which are necessary for the Palestinian people and to social groups and local communities in particular, depending on their specific needs (DW., interview, 22 April).

Table 20: Accountability to Future Generation \& National Goals, by Type of Organization

\begin{tabular}{|l|l|l|l|l|l|l|l|l|}
\hline \multirow{2}{*}{ Type } & \multicolumn{3}{|c|}{$\begin{array}{l}\text { Accountability } \\
\text { Generations }\end{array}$} & \multicolumn{3}{|c|}{ to Future } & \multicolumn{3}{c|}{ Accountability to National Goals } \\
\cline { 2 - 10 } & Weak & $\begin{array}{l}\text { Satisf } \\
\text { actory }\end{array}$ & Good & Total & Weak & $\begin{array}{l}\text { Satisfac } \\
\text { tory }\end{array}$ & Good & Total \\
\hline NGO & 6 & 7 & 4 & 17 & 4 & 9 & 4 & 17 \\
\hline CBO & 13 & 8 & 2 & 23 & 13 & 6 & 4 & 23 \\
\hline Subtotal & $\mathbf{1 9}$ & $\mathbf{1 5}$ & $\mathbf{6}$ & $\mathbf{4 0}$ & $\mathbf{1 7}$ & $\mathbf{1 5}$ & $\mathbf{8}$ & $\mathbf{4 0}$ \\
\hline Advocacy & 4 & 1 & 3 & 8 & 1 & 5 & 2 & 8 \\
\hline Services & 14 & 8 & 2 & 24 & 13 & 6 & 5 & 24 \\
\hline Combined & 1 & 6 & 1 & 8 & 3 & 4 & 1 & 8 \\
\hline Subtotal & $\mathbf{1 9}$ & $\mathbf{1 5}$ & $\mathbf{6}$ & $\mathbf{4 0}$ & $\mathbf{1 7}$ & $\mathbf{1 5}$ & $\mathbf{8}$ & $\mathbf{4 0}$ \\
\hline $\begin{array}{l}\text { Before } \\
1990 \text { s }\end{array}$ & 7 & 2 & 0 & 9 & 5 & 1 & 3 & 9 \\
\hline $1991-2000$ & 3 & 6 & 4 & 13 & 5 & 6 & 2 & 13 \\
\hline 2001-2010 & 9 & 7 & 2 & 18 & 7 & 8 & 3 & 18 \\
\hline Subtotal & $\mathbf{1 9}$ & $\mathbf{1 5}$ & $\mathbf{6}$ & $\mathbf{4 0}$ & $\mathbf{1 7}$ & $\mathbf{1 5}$ & $\mathbf{8}$ & $\mathbf{4 0}$ \\
\hline
\end{tabular}


To sum up the answers to the main question on which stakeholders NGOs are accountable to, the findings indicate that respondents believe that NGOs should, at least in theory, be accountable first to the public; although in reality they are accountable first to their donors. This is commonly agreed upon by the sample organizations. The surveyed BoD members, managers and staff stated that NGOs ranked second on their list accountability towards the Palestinian public. But in fact, NGOs priorities accountability to PA after donors because NGOs do not give much importance to the facets or dimensions of accountability to public and local community such as reporting, public participation in NGO decision making, incorporation of public needs and priorities into NGO programming, and disclosure of $\mathrm{NGO}$ information to the public.

\section{NGOs Legitimacy and Identity}

During focus group discussions and interviews, participants made the link between the issues of NGO transparency and legitimacy and alluded to four forms or sources of legitimacy for Palestinian nonprofit organizations: legal, representational, participatory and societal.

\subsection{Legal Legitimacy}

As of 2000, all organizations working in the oPT, including the preOslo generation, were obliged to (re)register with the MoI as not-for profit societies. The PA considers all unregistered groups, or those that have not re-registered in accordance to Law No (1) of 2000, as illegitimate although the society may be more tolerant of nonregistration or official seal of approval if the group adopts sociallyrelevant objectives and activities. Older organizations maintain their formal structures and political affiliations but they are also obliged to follow official accountability requirements.

\subsubsection{Representational Legitimacy}

Not all non-profit organizations have membership-based GAs thus passing the representatives of their real constituencies (i.e. youth, women, farmers, etc.) for a closed group of founders that take over organizations' governance structures. Close-membership entails that members or supporters of a given faction or political party are eligible 
211 for participation in internal elections, and benefiting from the organization's services or both. As in any institutions, powerful GA and/or BoD members dictate the results of elections in accordance with the interest of their factions or their own interests.

The major question about the link between governance and legitimacy is whether democratic elections, or lack thereof, cause the organization to maintain or lose its legitimacy. Eventually, the effectiveness and active participation of $\mathrm{BoD}$ members is more critical to the NGO's continued legitimacy. This applies to the pre-Oslo popular mass organizations that lost a chunk of their members to new NGOs for this reason. Today these organizations face a democracy crisis since no elections has been held for long time (MD., interview, 16 March). Both phenomena result in monopolized or centralized decision-making in the organizations and a disconnect from the grassroots and a loss of legitimacy stemming from the complete exclusion of the public from governance and decision-making processes. Participants stated that having local branches, centers and tangible services can enhance the legitimacy of NGOs and all types of non-profit organizations. The potential for greater legitimacy also hinges on overall transparency and adherence to membership criteria and written internal bylaws on the members' rights and duties as well as the policies and procedures to follow and ensure accountability. Furthermore, even with a wide base of volunteers, an organization still faces legitimacy questions and doubts because volunteers are mobilized causally or paid for their contribution, a practice that goes against the very concept of voluntarism in the public's mind.

\subsection{Participatory Legitimacy}

How organizations take decisions are conveyed them to the public turns out to be the major determining factor behind the unquestioned legitimacy by the public. In political institutions and other types of organizations, people (s)elect their representatives and delegate to them the responsibility for policy-setting and decisionmaking while those representatives remain accountable to the people. The above means that Palestinian NGOs will strengthen their legitimacy when they become more communicative with the public about the decision-making processes. Historically and prior to the 
creation of PA, factions ran most NGOs, took decisions on their behalf, and resolved their problems all within the structures of the political parties and according to their interests. By working very close to the people, non-profit organizations were less vertical in their structure (Sbieh, 2011). Today, the political ties still persist but nonprofit organizations conceal their political nature and relations by attempting to narrow down the decision making circles to a very few trusted individuals and donors, scarifying public participation in the process. But when things get tough with PA, these NGOs ask the political factions to confront the problem on their behalf (Sbieh, 2011).

After 1990, NGOs speech replaced the 'public' and 'constituencies' with a new terminology of 'beneficiaries' and 'target groups' thus rendering them untitled for participation in decision making and pushing them away from voluntary engagement in NGOs to notbelieving in or supporting the non-profit sector entirely. By doing so, the decision-making process reversed its direction to become topdown instead of bottom-up (Hamammi, 2000; Sbieh, 2011), made worse by the project-based approach to NGO work. Today, proposals promise donors that funding will be used to generate jobs and income for the poor and the unemployed because donors reject the real objective which is to protect Palestinians land from Israeli confiscation through agricultural development and extending support to farmers (Sbieh, 2011).

The growing disconnection between NGOs and public in the post-PA formation era with regard to $\mathrm{NGO}$ governance and mandates undermines their legitimacy in the public eyes. Some organizations opted to address the issue by increasing GA membership and grassroots involvement and enhancing cooperation with local counterparts. Others left their visions and mandates to be determined solely by few individual leaders. Those who follow the first option are looked upon favourably by the public, particularly when they cooperate with other local actors such as village councils and municipalities, or work under their umbrellas. The public's scepticism grows when this coordination is limited to institutions of the same political affiliations or to the implementation of separate activities or ad hoc projects. 
202 Organizational legitimacy could easily be enhanced if NGOs maintain a closer proximity to their populations through running local branches and centers, but most importantly though the inclusion of local communities in decision-making and NGOs functioning along with people's needs and priorities. Participatory need assessments and bottom-up planning then become insufficient to guarantee people trust if not followed by systematic public participation in implementation and monitoring of relevant programs designed in essence to satisfy actual needs to achieve a wider developmental and a positive, long lasting impact.

However, oPt communities have no real role in NGOs program development, fundraising or donor relations all of which consume the energy of an organization and its leadership. Weak organizational and service sustainability independently from foreign funding also cast serious shadows not only on the organization's accountability but also on its legitimacy in case it could not be sustained on local resources alone. Moe importantly, it will also question the main reason behind the creation of this organization in the first place unless it stays somehow relevant to the community (Awashra, 2011).

\subsection{Societal Legitimacy and Continued Relevance of NGOs}

Due to the multiplicity of social demands, many Palestinian organizations run a wide range of activities. In itself, it is not seen as a negative thing. Nevertheless focus group participants were more concerned with the unfair distribution of benefits and activities because of NGOs tendency to apply selective exclusion and/or preselection criteria irrelevant of need. On the other hand, the community tends to self-exclude if the NGO is perceived as having political ideas different from the community, unless direct financial or other benefits are offered to potential participants for the purpose easing rejection ${ }^{9}$. Relevance aside, the focus groups explained that local communities usually accept activities and services

\footnotetext{
${ }^{9}$ It's worth noting that PYU took decided to shun away from hiring political supporters as local coordinators and volunteers. "We decided to check the political identity at the center's door", said one coordinator. PYU women center in Beit Rima went even further and decided not even to discuss politics in the center in order to avoid any conflict between the women beneficiaries themselves or between the center and the community.
} 
of educational, cultural or economic nature, but are more hesitant to participate in or seek activities carrying political overtones or activities that aim to effect social changes in relation to gender, democracy, conflict resolution, human rights, or promotion of social justice ${ }^{10}$. The 'more acceptable' types of activities have limited or immediate positive impact on individuals unlike the social change variety perceived as 'luxurious', 'unrealistic' or 'contradictory to the community's believes, values and best interests' (Beit Rima focus group, 4 April).

The same group also indicated that while communities welcome interventions that impart skills and tangible benefits, ironically they end up enforcing social change more than 'awareness-raising' activities they fear. For example, women empowerment workshops rarely have concrete outcomes unlike income-generation or productive projects that ultimately enhance women's powers within the family and immediate community ${ }^{11}$. Focus group participants gave many anecdotes of women who actively participate in familial decision-making or developed persuasion skills to help older generations accept new idea or practices such as mixed-gender activities, women's employment, and men's assumption of further reproductive roles within the family.

In addition, people's perception of organizational legitimacy is directly linked to its financial stability. Both are mutually reinforcing and the lack of either one gives rise to the familiar claim of being called 'donor-driven'. In addition, organizations share common points of weakness most importantly the intensive investment on donor funding over quality and continuity of services. Thus more

\footnotetext{
${ }^{10}$ Many focus groups participants, especially women, expressed disinterest in participation in political activities such as peaceful street marches, protests or sitins although they were more receptive to taking part in educational activities that do not put them in direct confrontation with their families and/or with Palestinian and Israeli authorities

${ }^{11}$ NGOs and donors are to blame for this popular view on the automatic link between increased income and women's empowerment on the assumption that women will definitely have total control over the new resources. NGOs want to prove the positive impact of their projects and minimize community's resistance. In fact, studies around the world have shown that women's only economic projects have detrimental consequences on women because they change the gender relations in ways not always in the best interest of women and girls.
} 
21. organizations now tend to increase their revenues by creating their own income generation activities such as PC repair, child care centers, and catering services even when already proven unable to generate sufficient income or guarantee financial sustainability for the organization.

However, given that some NGOs have financial capability larger than political parties and some ministries (Sbieh, 2011), the public grew suspicious of these organizations, especially when their activities are of the non-service, 'luxurious' type. Dire financial resources weaken political parties and force their leaders to use the same tactics NGOs used for fund-raising from local and foreign sources. It also offers an explanation for political leaders search to secure paid positions in NGO top management or in the voluntary BoDs in the hope they shortly transition to paid management. This may consolidate the persons' political power or social standing yet the downside of this overlap is the creation of closed circles of profiteering elites, alliances and coalitions on the account of people plight, both of which eventually undermine political parties and non-profit organizations alike.

One of the case studies involves two local women's organizations in Beita $^{12}$, WDS and UPWC, engaged in poverty reduction and public policy dialogue, and women's participation and economic empowerment. Their projects target women, poor families, and marginalized groups through small-scale economic activities such as home gardens, animal husbandry, food processing and handicrafts in addition to necessary technical training in these areas and workshops to raise women's health, social and legal awareness.

Despite the similarity of their programs, both have different histories, mandates and working methods. UPWC seeks to "enable Palestinian national movement and women movement in particular to continue

\footnotetext{
${ }^{12}$ Four organizations are covered the case study in Beita, a rural town of 12,000 inhabitants located $12 \mathrm{KM}$ to south east of Nablus city. These CBOs are Beita Women Development Society (WDS), a local branch of the Union of Palestinian Women's Committee (UPWC), Beita Youth and Sport Centre, and Beita Charitable Society. UPWC is affiliated to PFLP and belongs to the 1980s generation of mass organizations while WDS was registered in 2007 and is affiliated to Fateh although perceived by the local community as less political than UPWC.
} 
struggle against the Israeli occupation and achieve national independence" (UPWC website, 2011). UPWC works against the PA economic and political polices than deepen oPt dependence on Israeli economy and work with women's cooperatives presented as an alternative to the PA-supported capitalist economic model (KT., interview, 10 May). It allows individuals and groups who do not receive welfare assistance from the MoSA for whatever reason to support them. On the other hand, WDS adopts the mainstream micro and small investment to poverty reduction through engagement with individual women of low economic status.

Certainly, UPWC is not the only organization with a preference for cooperatives. It is a popular approach among left affiliation NGOs because it enables people to "refuse handouts, adopt collective approach to identify solutions for their problems, share common values, and enhance their consciousness" (A.J., interview, 27 March). At a higher level the approach encourages people to take initiatives, introduce useful changes to their communities, and develop horizontal networks and relationships based on cooperation rather than power or stratification. Others claim that the left parties and factions promote cooperatives as a way to maintain public support through provision of some economic benefits (Kafreyat focus group, 19 March).

UPWC and WDS are avid advocates of collective economic approaches and dependence on local resources, whether land, raw material, human capital, or social relations. NGOs are not aware that micro-enterprise is designed to relief the state from its obligations towards the public or that they promote self-exploitation among the poor by engaging into very primitive and labour-intensive economic activities. They hardly make sufficient cash for their owners or generate large-scale employment as they tend not to create a host of support economic activities and services to generate good economy (NR., interview, 21 March). Even when cooperatives find support from communities and activists, economists believe that cooperatives work on a too-small scale to build a national economy. Unless they scale-up their economic operations, and receive the PA's political support and economic protection, it is unlikely that cooperatives 
206 would be sustainable or economically profitable (NR., interview, 12 March).

Sometimes, people's practices contradict their beliefs and interests ${ }^{13}$. Both UPWC and WDS do not plan projects at all or involve women directly if they do so that two premises are already violated: economic empowerment and women's participation. One BoD member stated that

"Women are bored of awareness workshops but they need real projects to generate some income for their families. The women are not asked if they want training or workshops on human rights and citizenship. As you know, the answer will be $\mathrm{NO}$ because people are not ready for democracy and human rights, or see that as one of their priorities" (KT., interview, 10 May).

Another GA member in the youth centre said:

"We do not need trainers coming to lecture us on democracy, get paid then go home. We know what democracy is because we did experience it in our daily life and national struggle. Before inviting people to democracy sessions, $\mathrm{CBO}$ s have to help in securing many basic needs. How can you convince a disabled, 40 years old man to attend such sessions when he could not secure long term medical treatment to his injured leg unless of course we offer him something more interesting?" (M.Moh., interview, 10 May).

To allow the public to decide requires two-way communication and constant dialogue to determine their needs and priorities. Organisational priorities must take into account both sets of group and individual needs but must give primacy to group's needs. For example;

When we started, men opposed us and banned their wives and sisters from attending our activities. After a while, men changed their positions and encouraged their women to register and benefit from

\footnotetext{
${ }^{13}$ For example Palestinian people believe that Israeli will not end its occupation of oPt, and is least likely to be pressured by the US and the UN to end it but when the Palestinians become stronger they can force Israel to withdraw. Not many people are working on ensuring Palestinian strength. In addition, many organizations run after donors' funds for financial support despite being critical of foreign aid and donors agendas.
} 
our projects. This is because we selected family-relevant activities, such as child-rearing, home economy, nutrition and other stuff possible to execute without a budget yet capable of attracting housewives and have direct results on the health of their families (BA., interview, 10 May).

That is WDS gained men's trust by selecting activities agreeable to men and women and by showing men the direct economic benefit they gain out of women's participation in WDS projects. But this may not be the only reason, because no man in Beita would accept Palestinian women's work in Israeli settlements regardless of the resultant economic benefits ${ }^{14}$.

What can be inferred from the above case studies are?

1. Legitimacy is derived only from the public because people do not trust inactive NGOs or those that neglect public interests.

2. $\mathrm{CBOs}$ have a more politically diverse membership base, thus political parties tend to be highly involved in their BoDs elections and composition and by doing so sacrifice organizational harmony and unity. The majority of Beita participants agreed that political parties' interference in organizational issues led to the weakening of these organizations.

3. Because their ultimate objective is to strengthen their members, politically affiliated NGO are always biased and focus on benefitting their supporters and party members without necessarily being corrupt.

\section{Conclusion}

The findings presented in this article illustrated the status of accountability to external stakeholders based on the premise that the non-profit sector is by definition concerned with public welfare and meeting their needs. The findings highlighted the failure of NGOs in meeting the most pressing needs of the public and the poor in particular. The upward-accountability also signals of the sector's

\footnotetext{
${ }^{14}$ To show that culture is important, Jericho women have openly worked in Israeli settlements close to Jerusalem and many claim that they have encouraged by their men to take work there.
} 
208 inability to consolidate its legitimacy or define an agenda or develop down-ward accountability. On top of that, political parties' involvement in the non-profit organizations is another factor that has compounded the sector's lack of public accountability, negative competitiveness, fragmentation, self-serving leadership, and exploitation as a substitute of political arena. In NGOs' opinion, the relationships to various stakeholders range from satisfactory to good especially where the PA, foreign donors, and political factions are concerned. The PA's hostility towards NGOs stems from suspicion of their political or donor affiliations and NGOs critique of PA policies and performance. However, NGOs accountability flows towards two powerful external stakeholders, the donors and the PA. Consequently, the NGOs are more concerned with upward accountability than with down-ward ones such as to the general public and the non-profit sector as a whole.

Within this context, NGOs and CBOs believe that a delicate balance can be achieved with the PA and political factions. With the PA, the NGOs suggest a greater role for line ministries in NGO oversight and regulation instead of assigning the $\mathrm{MoI}$ absolute power. The political factions can help consolidate NGOs external accountability without interference in NGOs affairs and functions. Moreover, political parties/factions can coordinate their activities and link their strategic visions, working in parallel with NGOs and public authorities to enhance national identity and collective rights. NGOs should focus on empowering people and support their steadfastness by delivering services and directing their accountability to constituencies, local communities, and the public at large. Finally, NGOs accountability dilemma is both a cause and a result of low level of public participation in NGOs affairs due to public's lack of trust and the general feeling that NGOs are distant, self-absorbed, and wasting foreign funds on activities lacking sufficient relevance to actual needs.

\section{REFERENCES}

AbdulHadi, M. ( 1997). NGO action and the question of Palestine challenges andProspects. Retrieved from

http://www.docstoc.com/docs/105960923/NGO-Action-and-theQuestion-of-Palestine

Al-M oaqat, F. (2007). The legal frame for organizing Palestinian NGOs work and its role in enhancing transparency and accountability. Palestine: 
Aman. AM AN. (2009). Transparency Report on Palestine. Palestine: Aman.

Awashra, R. (2011). Palestinian NGOs: community or unknown identity.

Social Science online Magazine. Retrieved from http://www. sw msa. net/articles. php?action $=$ show \&id $=2032$

Awashra, R. (2011). Palestine NGOs internal governance, general assembly and board of directors in the West Bank. Seyassat 16, 48-65.

Bishara, A. (1996). A contribution to the critique of civil society. Palestine: M uwatin-The Palestinian Institute for the Study of Democracy.

DeVoir, J., \& Tartir, A. (2009). Tracking external donor funding to Palestinian NGOs in the West Bank and Gaza 1999-2008. Retrieved from http://www.ndc.ps/uploads/File/Researches/Tracking\%20External\%20D onor\%20Funding.pdf.

Ebrahim A. (2003). NGOs accountability, accountability in Practice: mechanisms for NGOs. World Development 31 (5) 813-829.

Gray, R. Bebbington, J. and Collison D. (2006). NGOs, civil society and accountability: making the people accountable to capital. Accounting, Auditing, Accountability Journal, 19, 19-348.

Hamammi, R. (2000). Palestinian NGOs since Oslo- from NGO politics to social movements. Middle East Report, 214, 16-19+27+48. Retrieved from http://www.jstor.org/stable/1520188Accessed.

Hilal, J. (2006). The Palestinian political system after Oslo. Palestine: Muwatin- the Palestinian Institute for the Study of Democracy.Jad, I. (2003). The NGOization of the Arab women's movements. Retrieved from http://www.siyanda.org/docs/jad_ngoization.doc

Kamat, S. (2004). The privatization of public interest: theorizing NGO discourse in a neoliberal Era. Review of International Political Economy, 11 (1), 155-176.

Kilby, P. (2004). Accountability for empowerment: dilemmas facing nongovernmental organisations. Retrieved from www.hapinternational.org/pool/files/acct-empower.pdf

M clntyre-M ills, J., Vries, D., Christakis, A., \& Bausch, K. (2008) How Can We Break the Mould? Democracy, Semiotics and Regional Governance, Systems Research and Behavioural Science , 25: 305-321.

Muhsin , T. (2006). Prospects for structural shifts in the Palestinian political system. Retrieved from http://www . ahewar.org/debat/show . art. asp? aid $=67282$

Najim, A. (1996). NGO Accountability : A Conceptual Framework. Development Policy Review, 14 (4) 339-353.

Nakhleh, Kh. (1989). Community organisations and social change- nonGovernmental organisations and Palestine: the politics of money. Journal of Refugee Studies, 2, 113-124.

Samara ,A. (2001). Epidemic of globalization: ventures in world order, Arab nation And Zionism. California: Palestine Research and Publishing Foundation. 

Mythical Application and Discourses' Dogmatic Illustration. Palestine: Bisan Centre for Research and Development.

Shawa, S. (2000). NGOs and the discourse of 'civil society' in Palestine: a comparative analysis of four organizations. Retrieved from http://www.mafhoum.com/press4/119S21.htm.

Tandon R. (2010). Board Games: Governance and Accountability in NGOs. Retrieved from http://www.wtrc tmed.org/wtrc/resources/Board\%20Games.pdf

Weijiang , S. (2010). Why do "we" provide aid to North Korea? Retrieved from http://blog.paran.com/marinekslee/43408199. 